\title{
English Language Teaching: The Reflective Practices of an Oral Communication Class
}

\author{
Jowati Juhary $^{1}$ \\ ${ }^{1}$ Language Centre, National Defence University of Malaysia (UPNM), Kuala Lumpur, Malaysia \\ Correspondence: Jowati Juhary, Language Centre, National Defence University of Malaysia (UPNM), Kuala \\ Lumpur, Kem Sungai Besi, 57000, Malaysia. Tel: 12-334-400-9. E-mail: jowati@upnm.edu.my
}

Received: January 8, 2014 Accepted: February 10, 2014 Online Published: March 6, 2014

doi:10.5539/elt.v7n4p136 URL: http://dx.doi.org/10.5539/elt.v7n4p136

\begin{abstract}
Malaysia has come to a point where second and third languages become part of the requirements to be employed especially in the multinational and international companies. After gaining its Independence, English becomes the second language in Malaysia, and Bahasa Melayu is recognised as the official language of the country. This move has greatly impacted the education sector in Malaysia, and one of the challenges is that younger generation lacks English language competency. This can be supported by some recent surveys about employability of Malaysian graduates, in that one of the issues which hinders graduates to secure jobs is the inability to converse in English (see Mohamed Khaled Nordin, 2009; Noor Azina Ismail, 2011). Therefore, this article aims to examine the teaching and learning strategies and assessments for an oral communication course at the Defence University in Malaysia. At the same time, this article attempts to provide a basis for Continual Quality Improvement (CQI) for the course.The findings of this article are a series of reflective practices, observed and experienced by the author. These reflective practices can be used for further improvements and future references of the course.
\end{abstract}

Keywords: communicative language teaching, Defence University, military learning environment, oral assessments, oral communication

\section{Introduction}

\subsection{English Language Courses at the Defence University}

The National Defence University of Malaysia (NDUM) is the youngest public university in Malaysia. Since its inception in 2007, it has produced 1,482 graduates (the NDUM has had four graduation ceremonies since 2010 with 148 graduates, 2011 with 407 graduates, 2012 with 410 graduates and 2013 with 517 graduates). 75 percent of these graduates are now serving the Malaysian Armed Forces (MAF), and the rest are employed in various security and defence industries. One may argue that since the majority of the graduates are guaranteed postings in the MAF, these graduates may not need to be proficient in English. This argument comes from the very fact that the MAF uses Bahasa Melayu as its official language. Nonetheless, based on the author's observations, this is rarely the case. Every officer in the MAF now comes with a Bachelor Degree, and what distinguisheseach officerfrom the rest would be his/her communication and soft skills, including English language proficiency. Therefore, the graduates of the NDUM must possess an acceptable level of English language proficiency in order for them to be effective officers.

Hence, this article attempts to do two things. Firstly, it aims to examine the teaching and learning strategies and assessments for an oral communication course. Secondly, this article will become the document that records the Continual Quality Improvement (CQI) for the oral communication course. It is critical to emphasise that there are only two compulsory English language courses at the undergraduate level at the NDUM, namely English for Academic Writing and English for Oral Communication. There is, however, one English course, Basic Grammar and Vocabulary, which must be taken by students who obtained Bands 1 and 2 in the Malaysian University English Test (MUET) (the highest band in the examination is Band 6). The oral communication course relies totally on coursework through mostly formative assessments held, and there is no final examination for the course. The details of this course will be explained further in a later section.

Before this article goes further, some of the important questions about English language learning will be 
highlighted below, and the further this article goes, these questions will be answered in the various sections presented in this article. Amongst the significant questions are:

1) Why is an oral communication course important for the graduates of the NDUM?

2) How do the teaching and learning strategies affect the students' performance in the assessments?

3) What is the suitable strategy/approach to teaching an oral communication class?

4) How are students prepared for the assessments?

5) How do the assessments measure students' performance?

6) What are the changes that can be made to improve the teaching and learning of the oral communication course?

\subsection{The Significance of the Study}

Working in an unpredictable and unknown world today, the graduates are faced with various types of challenges. For both military cadets and civilian students, they must be equipped with relevant skills in order to stand out from thousands of other graduates. The way they carry and reflect upon current issues will set them apart from others. The NDUM is proud to extend its aspiration to all graduates, that is, to mould intellectual leaders of characters (ILC). One of these characters is the ability of students to be communicatively competent. Communicative competence comes from the confidence to speak eloquently and profoundly whenever necessary: at the right place and time and to the right audience.

As part of moulding future leaders of Malaysia, the ability to use English confidently is of the utmost importance. There are various factors that contribute to the ability of graduates to converse well in English. As this article is not able to cover all factors, it will emphasise on the tertiary training that the graduates have to undergo at the Defence University, particularly analysing one English course, and the learning activities used to train and develop students' confidence and communicative performance.Although reflective practices will be able to help the author in her future class, the more important issue is that information reported in the CQI will be able to help improve not only the teaching strategies of the author but also the education system at the NDUM (see Assessment for learning, formative assessment, 2004).

\subsection{Selected Literature Review}

The oral communication course at the NDUM adopts Communicative Language Teaching (CLT) strategies that look at how the language is used (Harmer, 2007). It is argued that students should be able to cope with the course well since they have been exposed to English since Standard One (the Malaysian system of education includes six years in primary and five years in secondary level). According to the primary and secondary English language curriculum, the school leavers are equipped with all four skills of English including grammar and vocabulary. As the final English course at the NDUM, the emphasis for the oral communication course is on the ability of students to use all skills for their daily life and future vocation.

Belchamber (2007) suggested four elements of CLT that could benefit students. First, CLT promotes communication amongst the students based on their own ability. Second, because students use English for communication, the educators can observe for accuracy as well as fluency of the students. Third, CLT promotes learning because students are not burden with being 'grammatically correct' all the time. Fourth, because of the promotion of learning, students' motivation is indirectly increased. What these benefits mean to students at the NDUM is that when the classroom environment promotes communicative aspect of a language, the students become more engaged and free to articulate their thoughts. Given the nature of the course, it is expected that students communicate and use English language confidently and effectively. CLT approach too promotes more authentic materials for teaching and learning. According to Richards (2006), the move towards authentic materials allows students to "experience" the real world ahead. In actual fact, CLT puts the learner as the focus of teaching and learning (Savignon, 2002). This is in line with the aim of the Ministry of Education, Malaysia that emphasises on Student Centred Learning (SCL). In addition, Newton, Yates, Shearn, and Nowitzki (2010) found that CLT acknowledges and responds to diverse groups of students. Because students have different backgrounds coming into English classes, CLT allows students to tap into their old knowledge and use it in different learning contexts in the classroom.

Notwithstanding this, CLT is not without its critics. For one, it is argued that CLT must strike a balance between communicative abilities and a more direct instruction of language which includes grammatical and lexical features (Spada, 2007).Further, some concerns over the use of CLT are that it fails to take into consideration the local conditions of learning and students' needs (Hunter, 2009). The summary of the critics comes in the forms 
of several key misconceptions about adopting CLT in English language classroom. Thompson (1996) put forward four misconceptions including CLT classroom does not teach grammar, teaches only speaking, means pair works and expects too much from the teacher. What these misconceptions reflect is the surface understanding of CLT approach itself. Although it is argued that no one approach or method is superior to the other, this article highlights CLT because it is the basis of all the activities and materials used in the oral communication class at the NDUM.

\subsection{The Assumption}

Because data analysis for this article will not involve statistical enquiry, the author argues that an assumption would be a better option rather than a hypothesis. Thus, this study assumes that: The students are able to achieve all course outcomes for the oral communication course at least at a B grade because the focus of the course is communicative competence. The assumption focuses on the teaching and learning activities and assessments used in the oral communication course, and will answer the questions posited earlier.

\section{Method}

This section describes the research procedures of this article. Because of its nature, the article heavily relies on quantitative data as well as personal observations of the author. The author is also the English instructor at the Defence University. For the purpose of this article, she used one class of the oral communication that she was assigned to teach. Thus, all students in the class were the direct subjects of this small scale study.

\subsection{Data Collection Methods}

One oral communication class was used as the basis of data collection and analysis. The data were collected during Semester 1, Academic Session 2013/2014 which ran from September 2013 to January 2014. There were 14 weeks of lectures and tutorials, and the assessments were conducted within this period. The course used an in house publication of teaching and learning module, covering about 20 hours of face-to-face sessions. Students were also provided online support and learning materials through the Learning Management System (LMS) of the NDUM.

\subsection{Participants (Subject) Characteristics}

There were 28 second year students in the class that were taught and observed by the author. Of this number, eight were ladies and the rest gentlemen. In terms of categories of students, only nine were civilians and the rest were military cadets. The unique element of the defence university is that it is a residential campus. Further, due to its boutique university status, the student population is capped at 5,000 only. This allows every student to enjoy the life on campus without having to worry about the transportation and other logistic issues. In terms of the MUET achievement, one student obtained Band 4, 12 Band 3 and the rest Bands 1 and 2. This suggests that 15 students had undergone the extra English course during their first year at the university.

\subsection{Sampling Procedures}

As described earlier, the total number of subjects was only 28, which is just one class of the oral communication course. The total number of students taking the course for Semester 1, Academic Session 2013/2014 was 384, and they were divided into 14 classes. These students were grouped based on their academic majors. Nevertheless, students had the power to choose their language slots depending on their schedules and perhaps the instructors. Thus, these 28 students chose to be in the author's class.

\subsubsection{Limitation of the Sample Size}

Although the number of respondents was relatively small, the author has no control over it because she was only given one class of oral communication. She could also have asked other instructors to participate in the study, but she opined that the measures and approaches to teaching may be different, thus affecting the results. Nevertheless, as a preliminary study into reflective practices, the author hopes to extend this study to the next cohort taking the course and to also invite participation of other instructors.

\subsubsection{Research Design}

The subjects underwent all 14 weeks of lectures, tutorials and online activities. Each student was also individually observed, and the progress is recorded in a progress sheet that records the students' oral assessment achievement. The oral assessments were also video taped in order to help students identify their weaknesses for improvements. During the final meeting with the author (outside of the 14-week period), students were asked several questions collectively. These questions include:

1) What have changed in your oral communication abilities from the first to the last week of class? 
2) How do you see your own progress from the first to the last assessment?

3) Which assessment is the most difficult? Why?

\section{Results}

This section presents the findings of this study. Because of the nature of this article, there is no statistical analysis performed. Presentation of collected data is in numerical figures only. The details of the subjects are illustrated in Table 1. As shown in the table, the number of female students is relatively small. It also shows that the class does not have naval cadets. The NDUM houses all three military services. This scenario depicts the needs and demands of the services towards certain academic majors. All these students are majoring in Computer Science, either in Artificial Intelligence or Computer Security.

Table 1. The demographic information of the subjects

\begin{tabular}{llll}
\hline & Male & Female & Total \\
\hline Gender & 20 & 8 & 28 \\
Military Cadets & 18 & 1 & 19 \\
- Malaysian Army & 12 & 1 & 13 \\
- Royal Malaysian Air Force & 6 & 0 & 6 \\
Civilians & 2 & 7 & 9 \\
\hline
\end{tabular}

The subjects were asked three questions during the last meeting with the author. The overall grade over 100 percent was shown individually to each student, and he/she must acknowledge the grade by signing the Assessment Report Sheet. Then, about 20 minutes were spent on asking the students collectively these three questions. The responses came in various replies, and the author arranges them accordingly as illustrated in Tables 2, 3 and 4 below.The survey was conducted in two parts. Firstly, for Questions 1and 2, the students were asked about skills that they had improved, and the responses became the themes. For the other question, the author used the assessments throughout the course as the themes. Secondly, the author asked how many of the subjects were affected by each theme, and the subjects raised hands to respond. Thus, these tables actually present the counting of the raised hands for each theme.

Table 2. Themed responses for question 1

\begin{tabular}{lc}
\hline Themes/Questions & $\begin{array}{c}\text { What have changed in your oral communication abilities from } \\
\text { the first to the last week of class? }\end{array}$ \\
\hline Confidence Level & 28 \\
Appropriate Use of Gestures, & 10 \\
Postures, Facial Expressions & 5 \\
Language Skills (Grammar) & 17 \\
Language Skills (Listening) & 26 \\
Language Skills (Speaking) & 0 \\
No Changes/No Progress & \\
\hline
\end{tabular}


Table 3. Themed responses for question 2

\begin{tabular}{lc}
\hline Themes/Questions & $\begin{array}{c}\text { How do you see your own progress from the first to } \\
\text { the last assessment? }\end{array}$ \\
\hline No Changes/No Progress & 0 \\
Excellent & 7 \\
Good & 12 \\
Fair & 19 \\
\hline
\end{tabular}

Notes: Students can only raise their hands one time

Table 4. Themed responses for question 3

\begin{tabular}{lc}
\hline Themes/Questions & Which assessment is the most difficult? Why? \\
\hline Public Speaking & 2 \\
Military Briefing & 7 \\
Oral Commentaries & 15 \\
Drama & 0 \\
Tests & 4
\end{tabular}

Notes: Students can only raise their hands one time

The second part of Question 3 showed that students opined that Oral Commentaries were the most difficult assessment because of two reasons. Firstly, this is the only assessment that was conducted impromptu, that means students were not given the topic to prepare before the assessment started. Secondly, the students admitted that they lack vocabulary to give appropriate comments on the video clips shown. As a result, there was many "silent moment" during the assessment. These two reasons are reflected in the actual performance of the students who managed to score 11.5 of 15 as the highest point for Oral Commentaries. The lowest mark attained by the students for this assessment is 8. The second most difficult assessment chosen by the students was Military Briefing. The common reason given was that they had never seen Military Briefing (for civilian students) and as such they lack the exposure. Some military cadets too commented that they themselves had never given a brief before, thus it was a good experience having done it in the course, albeit with some difficulties.

\section{Discussion}

This section will accomplish the aims of the article. The first aim, which is to examine the teaching and learning strategies and assessments for an oral communication course, is achieved by analysing the reflective practices of the author. At the same time, it is critical for those who want to reflect their teaching to understand the needs of the students. The oral communication course is designed to assist students to develop their communication skills. Therefore, the majority of the assessments are considered formative in nature. This is because the marks for these assessmentsare used to improve learning. For example, Public Speaking 1 (PS1) is used to improve the second public speaking. According to Chappuis (2009), it is not the assessments themselves that are labelled as "formative", rather how the information elicited is used to enrich teaching and learning. For this oral communication course, only two written tests are used for the summative purpose, that is, to make judgement about students' competency on literary elements and verbal and non verbal communication concepts. Moreover, all assessments are based on the principles of CLT that promote communicative competence. Hence, the course outcomes of the course are,

1) State correctly the principles and mechanics of speech production (CO1)

2) Identify correctly literary elements $(\mathrm{CO} 2)$

3) Differentiate spoken discourses (CO3)

4) Classify different forms of verbal and non verbal communication (CO4)

5) Respond to various types of presentation (CO5)

Thus, the discussion and analysis will measure how far students have achieved these five outcomes based on the assessments' marks. This allows the article to achieve its second aim which is to provide a basis for the CQI of 
the course. Before analysing further, it is critical to identify the importance of reflective practices. Reflective practices mean the ability of educators to reflect what was done during the teaching process, and further improve on the practices in the next class. Because educators may not be able to reflect every day, the Malaysian tertiary practices suggest a semesterly CQI process, thus a semesterly reflective practice is expected.

The influential thinkers on reflective practices came in the late nineteenth century with Dewey, followed by other prominent scholars such as Schon, Kolb and Gibbs (see Rushton \& Suter, 2012). There are various definitions of reflective practices but the author is keen to use the one provided aptly by Cunningham (2001) who suggested that educators engage in continuous cycle of self observation and self evaluation in order to understand their own reactions to classroom teaching and learning. According to Cunningham too, the main goal is "to observe and refine teaching practices in an ongoing basis." This definition allows the author to improve her teaching, and at the same time to reflect upon the suitable strategies to teach an oral communication class.

Reflective practices too suggest that the author has to revisit her strategies for teaching the future oral communication students. As a tool for professional development, reflective practices permit the author to have a greater sense of self awareness about the nature and impact of her teaching strategies onto the students (Osterman \& Kottkamp, 1993). Further, according to Benson, Hardy, and Maxfield (2001), reflective practices revolve around the learning process that is iterative. The author argues that reflective practices then are not only about making her a better educator, but they are also about making the students more aware of their learning processes and competency.

Table 5. Course outcomes (CO) and students' achievement based on assessments

\begin{tabular}{|c|c|c|c|c|c|}
\hline & $\begin{array}{l}\text { Tests } \\
\text { (Summative) }\end{array}$ & $\begin{array}{l}\text { Public Speaking(PS) } \\
\text { (Formative) }\end{array}$ & $\begin{array}{l}\text { Military } \\
\text { Briefing } \\
\text { (Formative) }\end{array}$ & $\begin{array}{l}\text { Oral } \\
\text { Commentaries } \\
\text { (Formative) }\end{array}$ & $\begin{array}{l}\text { Drama } \\
\text { (Formative) }\end{array}$ \\
\hline $\begin{array}{l}\text { State correctly the } \\
\text { principles and } \\
\text { mechanics of } \\
\text { speech production }\end{array}$ & & $\begin{array}{l}\sqrt{ } \\
\text { PS1 [B - 13; C-13; } \\
\text { D-2] } \\
\text { PS2 [B - 7; C - 21] }\end{array}$ & $\begin{array}{l}\sqrt{ } \\
{[\mathrm{A}-6 ; \mathrm{B}-} \\
17 ; \mathrm{C}-5]\end{array}$ & $\begin{array}{l}\sqrt{ } \\
{[B-15 ; C-13]}\end{array}$ & $\begin{array}{l}\sqrt{ } \\
{[\mathrm{B}-28]}\end{array}$ \\
\hline $\begin{array}{ll}\text { Identify } & \text { correctly } \\
\text { literary } & \text { elements } \\
\text { (Test 2) } & \end{array}$ & $\begin{array}{l}\sqrt{ } \\
{[\mathrm{A}-12 ; \mathrm{B}-} \\
15 ; \mathrm{C}-1]\end{array}$ & & & & \\
\hline $\begin{array}{l}\text { Differentiate } \\
\text { spoken discourses }\end{array}$ & & $\begin{array}{l}\sqrt{ } \\
\text { PS1 [B - 13; C - 13; } \\
\text { D - 2] } \\
\text { PS2 [B - 7; C - 21] }\end{array}$ & $\begin{array}{l}\sqrt{ } \\
{[\mathrm{A}-6 ; \mathrm{B}-} \\
17 ; \mathrm{C}-5]\end{array}$ & $\begin{array}{l}\sqrt{ } \\
{[B-15 ; C-13]}\end{array}$ & $\begin{array}{l}\sqrt{ } \\
{[\mathrm{B}-28]}\end{array}$ \\
\hline $\begin{array}{l}\text { Classify different } \\
\text { forms of verbal and } \\
\text { non verbal } \\
\text { communication } \\
(\text { Test } 1)\end{array}$ & $\begin{array}{l}\sqrt{ } \\
{[\mathrm{A}-6 ; \mathrm{B}-} \\
12 ; \mathrm{C}-4 ; \mathrm{D} \\
-6]\end{array}$ & & & & \\
\hline $\begin{array}{l}\text { Respond to various } \\
\text { types of } \\
\text { presentation }\end{array}$ & & $\begin{array}{l}\sqrt{ } \\
\text { PS1 [B - 13; C }-13 ; \\
D-2] \\
\text { PS2 [B - 7; C }-21]\end{array}$ & $\begin{array}{l}\sqrt{ } \\
{[\mathrm{A}-6 ; \mathrm{B}-} \\
17 ; \mathrm{C}-5]\end{array}$ & $\begin{array}{l}\sqrt{ } \\
{[\mathrm{B}-15 ; \mathrm{C}-13]}\end{array}$ & $\begin{array}{l}\sqrt{ } \\
{[\mathrm{B}-28]}\end{array}$ \\
\hline
\end{tabular}

Notes: $\sqrt{ }$ denotes the relations between the course outcomes and the assessments, that is, what the assessments will measure in terms of the students' ability at the end of the course. For the information in [], it shows the number of students who scored certain marks and the associated grades following this scale: 5 percent assessment - A (4); B (3.25); C (2.5); D (2); E (1.5); 10 percent assessment - A (8); B (6.5); C (5); D (4); E (3); and 15 percent assessment - A (12); B (9.75); C (7.5); D (6); E (4.5) 
Based on Table 5, it is apparent that the students are overall at the B grade. This is because for all assessments, with the exception of Public Speaking 2 (PS2), the majority of the students scored a B (as stressed in the note below the table, the assessments had three levels of marks including 5,10 and 15 percent; thus B for each type was 3.25, 6.5 and 9.75 and above respectively). The subsequent sub sections will report on the reflective practices for future teaching improvement of the author based on the course outcomes.

\subsection{Course Outcome 1: State Correctly the Principles and Mechanics of Speech Production}

This course outcome was measured by five assessments including two Public Speaking ( 5 and 10 percent), Military Briefing, Oral Commentaries and Drama (each is 15 percent). The students will be deemed to have achieved this outcome when they are able to apply the theories learnt in classes during the assessments. The students and the author spent about five hours on phonetics and phonological aspect of speech production during the tutorial sessions. The teaching and learning activities for these lessons included drilling on pronunciation and the use of the audio laboratory for listening to samples of pronunciation. The majority of students scored B for the oral assessments. Nevertheless, six students were given an A for Military Briefing and the rest of the formative assessments did not have students scoring an A. The author opines that this is due to two main factors. Firstly, the students appeared to be quite comfortable presenting their briefing especially the military cadets because they are exposed to it. In fact some of the students are also rank holders; this suggests that they are trained from time to time to give their own briefing to other junior cadets. Secondly, the military briefing requires students to present with the assistance of slides. As such, some of the scores came from appropriate use of power point presentation. The students too benefit from the slides because these boosted their confident level to brief; a ready-to-read-note helps them to remember their points.

Part of educating future intellectual leaders of characters is to ensure that the students are at ease when using the language. The author argues that should the students be given more time to practise their sound production mechanics, their grades would be better, or at least more will be able to score an A. Apart from that, the learning environment and experience of the NDUM can play a huge role to inculcate English language proficiency. A concerted effort between all faculties and departments in helping to create and foster aconducive environment for English to grow and develop will definitely be the key to encourage students to use the language outside of the English classes. Notwithstanding this, the author has limited resources to change the environment. One of the approachesthat the author promoted to the students is to use online dictionary and listen to how words are pronounced, and then imitate them.

\subsection{Course Outcome 2: Identify Correctly Literary Elements}

The oral communication too exposes students to a literary text. The text used for this particular semester is titled "A Question of Dowry" by Siew Yue Killingley. The use of literary texts allows students to tap into their inner self on issues surrounding them. But the most important aspect to be emphasised when reading literary texts is to inculcate critical thinking abilities and sharpness of minds. Generally, the students scored an A, B and C with 12, 15 and 1 students respectively in Test 2. It can be concluded that the students were able to understand the text, including its literary elements. The elements tested were on characters and characterisation; plots; and themes. The students were also asked to give their opinions on the cultural issues presented in the story, and most of them excelled at this by giving appropriate examples from their surroundings.

The author concludes that the students were able to achieve this outcome because they are familiar with the customs and traditions of Indian families. Although there is only one Indian student in the class, Malaysia is a multiracial society being the Indians are amongst the largest three races. As such, exposures to diverse cultures and customs have given the students the opportunity to argue on issues academically. However, as much as the author wants all students to score an A for Test 2, it needs to be stressed that this outcome was tested using a written method, and not orally. Moreover, since the tests were used for summative purposes in the course, the author argues thatthe two tests conducted were the only mechanism that can help her to differentiate good and weak students.

\subsection{Course Outcome 3: Differentiate Spoken Discourses}

Similar to the first course outcome, this outcome was also measured by two Public Speaking, Military Briefing, Oral Commentaries and Drama Presentation. Again, this is an indirect outcome where the students had to use all the knowledge gained during their lecture and tutorial sessions for the various types of oral assessments. This is because although the students need to do oral presentation, it is not about standing and speaking only. Each assessment has its own formats and styles of presentation. Thus, students must be able to differentiate the formats and styles accordingly. As commented by students during the survey, the most difficult assessment was Oral Commentaries. Judging from Table 5, most students scored between a B and C; 15 students received a B 
and 13 students a $\mathrm{C}$. The author strongly opines that the reasons for this are twofold.

Firstly, the students were not trained to speak on topics or issues that are not familiar to them. Apart from the fact that they lack vocabulary (as admitted by them in the previous section), the students appeared to shy away when English is being spoken to them. They tried as much as possible to avoid using the language and at times, this is obvious in the classroom learning itself. Because of this attitude, they were not able to embrace the language whole heartedly. They may know the structure, but since they lacked practise, they failed to use the structure competently. In all fairness to the students, some of them were really diligent and tried to use the language. Nonetheless, the environment at the NDUM may fail to support this kind of effort to the fullest, leaving the students disappointed and demoralised.

Secondly, Oral Commentaries require students to be actively engaged with the stimulus presented to them. Because they were assessed based on how accurate and true their description and analysis of the stimulus, they are in need of more activities that allow them to express themselves analytically. At the same time, the students were put in pairs that were randomly chosen by them, and this made the assessment more challenging because if their partners were weak or not responsive, they had to do the commentaries "alone". What can be discerned from this assessment is that the students must be given more impromptu stimuli to invoke their thoughts so that when they were asked to express their opinions, they could do so more articulately and effectively. In her future class, the author plans to arrange for a daily commentary on current issues or pictures/video clips used as stimuli, and the speakers are chosen on the day itself. For the 42 hours of face-to-face sessions, each student will have about two times of spontaneous oral commentaries of five minutes each time. By so doing, the students are provided training to speak impromptu critically and competently.

\subsection{Course Outcome 4: Classify Different Forms of Verbal and Non Verbal Communication}

This outcome was measured by Test 1 which focused on the theories of verbal and non verbal communication including the strategies, hindrances and the like. Six students scored an A, 12 students a B, four students obtained a C, and six students obtained a D. This is the only assessment that has four grades awarded to the students. About four hours were spent discussing with the students issues and concepts of verbal and non verbal communication. Live demonstrations were also done in order to enhance students' understanding of the concepts. Albeit, the author realises that some of the students really need more worldly exposure on cross cultural communication especially those that involve foreign customs and practices. This is because the concepts of verbal and non verbal communication must be visualised so that students are able to grasp what they have never seen or experienced before. Although the author shared video clips about greeting gestures from various countries, the students' metacognitive ability was rather limited due to various reasons including their background knowledge.

The test consisted of four main questions, and they were basically structured questions. Nonetheless, the students were expected to answer based on not only the module provided to them, but also based on the live demonstrations performed, video clips shown as well as their experiences. Then, the author concludes that the future oral communication class may as well integrate some forms of online asynchronous or synchronousinteraction between them and students from foreign lands. This may well increase the students' self confidence as well as their exposure to other nations' customs and practices. More importantly, the students can start to reflect upon themselves as future intellectual leaders of characters who are engaging globally.

\subsection{Course Outcome 5: Respond to Various Types of Presentation}

The last course outcome was also measured by similar assessments to the first and third course outcomes. The ability of the students to not only understand the formats and concepts of each type of presentation, but also to give appropriate responses using the correct formats and concepts is very much expected. All students scored a B for Drama and the marks ranged from 10 as the lowest to 11.5 as the highest. The students could have done better if they 'acted' rather than read the scripts during the drama presentation. In addition to that, the students might be able to achieve an A if they concentrated on the voice production as well as postures, gestures and facial expressions. All these elements were part of the syllabus for the oral communication course.

The author argues that the students could achieve an A for this assessment given more time to practise in their groups. The time will need to be spent on "perfecting" the way the dialogues is delivered. In addition, the time will be used too for bonding the "characters" in the drama presentation, and of course the extra time will permit the students the opportunity to understand and memorise their lines. Nonetheless, time is questionably limited at the defence university where military cadets are also doing their military and physical training weekly. Thus, here comes the advantage of the LMS to help students. This will be explained further in the next sub section. 


\subsection{Revisiting the Assumption}

The assumption posited earlier suggests that students are able to achieve all course outcomes at least at a B grade. Based on Table 5, it can be concluded that this assumption appears to be substantiated. The individual grades of the students show that 26 students scored a B and two students achieved an A. Although this is the case, the author opines that there are three key issues that must be revisited by the author herself and perhaps to be brought to the attention of the course coordinator. Firstly, because grammar and structural components were not taught in this course, some students were not able to use grammar accurately.As a result the ideas that they tried to convey became misleading. Focusing on communicative competence, that is, using CLT as the basis of teaching and learning, students are encouraged to articulate their ideas confidently without having to 'think' about their grammatical accuracy. As stopping the students in the middle of their spoken discourses may demotivate the students (see Wong \& Barrea-Maryls, 2012), the author argues that there must be venues to highlight their mistakes so that they can relearn their grammar skills. A more systematic approach to integrate grammar lessons in this course must be made because judging from the students' oral assessments, there were multiple grammatical errors committed by all students.

Secondly, the course outcomes must be revisited and redefined. The course outcomes used Bloom's taxonomy of cognitive, affective and psychomotor domains when they were formulated. The author admits that some of the course outcomes are fairly difficult to measure. For example, the fifth course outcome expects the students to respond to various types of presentations. The author argues that responding may mean that the students become passive learners in the classroom, or they just perform "mental reflection" without having to counter argue or respond to the presentation orally or physically. Thus, when five assessments were put to measure this course outcome, it was rather challenging to do so. Further, the assessments too must be refined in order to see how accurate they are at achieving the course outcomes. At the same time, the rubrics for each assessment should be reviewed as well. For example, out of 10 marks for PS2, how much should be awarded for vocal quality including pace and articulation or gestures including facial expressions and postures? Thirdly, the author strongly suggests that technology to be used for this course to the fullest especially the technique of flipping classroom. Flipping classroom allows the educators to put their teaching videos, lecture notes or materials online, and students will have to access the materials before coming to classroom. This gives students more chance to talk about the materials that they have accessed, and as such more dialogues will happen in the classroom (see Tucker, 2012).

The author opines that the suitable strategies to teach an oral communication class at the defence university are a combination of several strategies mainly two of them. The first one is to provide ample theories and examples for the students to understand the mechanics of sound production. Moreover, some grammatical and structural lessons should also be incorporated to ensure that students are able to articulate their thoughts in English effectively. These lessons could be done using the materials used to practise the phonetic symbols. Most crucially, the lessons could be provided online through the LMS of the NDUM; this will save face-to-face time which is only 42 hours per semester. Following the understanding of these theories, the second strategy is to provide morespeaking sessions for the students. These speaking sessions must be facilitated in such a way that the students are coached to develop their verbal and non verbal communicationability. Because the author only spent 42 hours (three hours weekly) with the subjects, here lies the importance of flipping classroom, where all the theories should be placed, and students come to face-to-face sessions "eager" to ask questions and to apply the theories hands on. Although this appears to be relatively easy for the teaching and learning process, it is actually more perplexing because students are now prepared to challenge what they have listened to and read, and to apply the knowledge that they have gained online. The task of the author in her next semester's groups will be to assist the students' speaking sessions whilst not forgetting that she also has to monitor the progress of every student in the class.

\subsection{Limitations}

Because the author is only at this point documenting her personal reflective practices, it has to be admitted that the article lacks statistical analysis because of two important reasons. Firstly, the number of subjects is fairly small; only one class that was involved in the reflective practices. Secondly, perhaps the course outcomes should be validated further in order to be fair to the performance of the students in the assessment. Although these outcomes have been reviewed several times after one cycle of academic year, they definitely can be improved in order to reflect the nature of the course and measure the real performance of the students. More direct outcomes, rather than indirect ones, could be integrated in the existing course outcomes. Further studies will have to look into this issue. 


\section{Conclusion}

To conclude, the author keeps reminding herself that the purpose of assessment is to support learning (see Black \& William, 2012). As such, aligning the course outcomes to the assessments is no easy task, and it is not a solo journey of the author; all teaching the oral communication course must find the consensus on these important matters. As acutely summarised by Daugherty, Black, Ecclestone, James, and Newton (2012), educators must think of how best to construct the assessments by understanding the formulation of the course outcomes as "a complex, non linear, interacting system with the ultimate goal being a synergy that embraces curriculum, pedagogy and assessment." Given this, the teaching staff of the course should sit down after completing their CQI in order to discuss the strengths and weaknesses of their teaching, materials used and ultimately reassess the course outcomes and the assessments used to achieve them.

Hence, this article has fulfilled its two aims; to examine the teaching and learning strategies for an oral communication course and to prepare the CQI documentation. The next critical step is to present this CQI to the higher authority. Individually, this course may have contributed to the students' academic performance. Nonetheless, the authority will have to look at the overall courses taken by these 28 students to conclude whether they have achieved the programme educational outcomes of Computer Science. Given this small sample of the students' performance, the author argues that the students will still need a lot of polishing in terms of English language proficiency and communicative competence before they can join the Malaysian workforce.

\section{Acknowledgements}

The author thanks the students of the oral communication class, all 28 of them. The author also wishes to thank the NDUM for supporting the study by allowing the author to document and write on her reflective practices for CQI purposes.

\section{References}

Assessment for Learning, Formative Assessment. (2004). OECD/CERI International Conference "Learning in

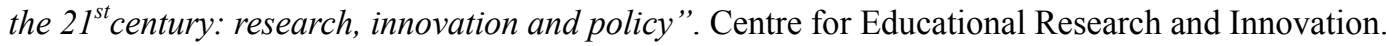

Belchamber, R. (2007). The Advantages of Communicative Language Teaching. The Internet TESL Journal, $\operatorname{XIII(2).~Retrieved~from~http://iteslj.org/Articles/Belchamber-CLT.html~}$

Benson, R., Hardy, L., \& Maxfield, J. (2001). The international classroom: Using reflective practice to improve teaching and learning. ASCILITE Conference Proceedings, 83-92.

Black, P., \& William, D. (2012). Assessment for learning in the classroom. In J. Gardner (Ed.), Assessment and Learning (pp. 11-32). Los Angeles: Sage. http://dx.doi.org/10.4135/9781446250808.n2

Chappuis, J. (2009). Seven strategies of assessments for learning. New York: Pearson.

Cunningham, F. M. A. (2001). Reflective teaching practice in adult ESL settings. Retrieved from http://www.cal.org/caela/esl_resources/digests/reflect.html

Daugherty, R., Black, P., Ecclestone, K., James, M., \& Newton, P. E. (2012). Alternative perspectives on learning outcomes: Challenges for assessment. In J. Gardner (Ed.), Assessment and Learning (pp. 72-86). Los Angeles: Sage. http://dx.doi.org/10.4135/9781446250808.n5

Harmer, J. (2007). The practice of English language teaching. Essex: Pearson Education Limited. http://dx.doi.org/10.1093/elt/ccn029

Hunter, D. (2009). Communicative Language Teaching and the ELT Journal: A Corpus-based approach to the history of a discourse ( $\mathrm{PhD}$ thesis, Centre for Applied Linguistics, University of Warwick).

Nordin, M. K. (2009). Keynote Speech during a seminar on "Enhancing graduate employability: Issues, Concerns and the Way Forward". Marriott Hotel Putrajaya Kuala Lumpur Malaysia, 21 July.

Newton, J., Yates, E., Shearn, S., \& Nowitzki, W. (2010). Intercultural Communicative Language Teaching. A Report to the Minstry of Education, Victoria University of Wellington.

Noor Azina Ismail. (2011). Graduates' characteristics and unemployment: A study amongst Malaysian graduates. International of Business and Social Science, 2(16), 94-102.

Osterman, K. F., \& Kottkamp, R. B. (1993). Reflective Practice for educators: Improving schooling through professional development. Newbury Park, California: Corwin Press, Inc.

Richards, J. C. (2006). Communicative Language Teaching Today. Cambridge: Cambridge University Press.

Rushton, I., \& Suter, M. (2012). Reflective Practice for teaching in lifelong learning. Cambridge: Open 
University Press.

Savignon, S. J. (2002). Interpreting Communicative Language Teaching: Contexts and Concerns in Teacher Education. New Haven: Yale University Press.

Spada, N. (2007). Communicative Language Teaching: Current Status and Future Prospects. In J. Cummins, \& C. Davison (Eds.), International handbook of English language teaching Part 1 (pp. 271-288). New York: Springer. http://dx.doi.org/10.1007/978-0-387-46301-8_20

Thompson, G. (1996). Some misconceptions about Communicative Language Teaching. ELT Journal, 50(1), 9-15. http://doi:10.1093/elt/50.1.9

Tucker, B. (2012). The flipped classroom: Online instruction at home frees class time for learning. Education Next, Winter, 82-83.

Wong, C. C. Y., \& Barrea-Marlys, M. (2012). The role of grammar in Communicative Language Teaching: An exploration of second language teachers' perceptions and classroom practices. Electronic Journal of Foreign Language Teaching, 9(1), 61-75.

\section{Copyrights}

Copyright for this article is retained by the author(s), with first publication rights granted to the journal.

This is an open-access article distributed under the terms and conditions of the Creative Commons Attribution license (http://creativecommons.org/licenses/by/3.0/). 